\title{
Filmar os terreiros, ontem e hoje
}

\author{
César Guimarães ${ }^{I}$ \\ https://orcid.org/0000-0001-8616-6279
}

${ }^{I}$ Universidade Federal de Minas Gerais, Belo Horizonte, MG, Brasil.

Doutor em Literatura Comparada pela FALE (UFMG).

Professor Titular do Departamento de Comunicação da FAFICH (UFMG).

http://dx.doi.org/10.1590/1981-5344/3891

A partir da crítica que as lideranças políticas e religiosas das comunidades de terreiro têm endereçado às representações ficcionais e documentais em torno das religiões afro-brasileiras, este artigo discute as novas modalidades de figuração do "povo de santo" no cinema, no momento em que ele assume sua auto-representação.

Palavras-chave: Religiões afro-brasileiras. Comunidades de terreiro. Documentário.

\section{Filming the terreiros, yesterday and today}

Based on the critique that the political and religious leaderships of the terreiro communities have addressed to the fictional and documentary representations around the Afro-Brazilian religions, this article discusses the new modalities of figuration of the "people of santo" in the cinema, at the moment in which he assumes his selfrepresentation.

Keywords: Afro-Brazilian religions. Terreiro communities. Documentary.

Recebido em 12.03.2019 Aceito em 12.03.2019 
Em abril de 2018, atendendo ao convite do prof. Rubens Alves da Silva, participamos do I Seminário NEPPAMCs: Patrimônio e Mediações Culturais na Contemporaneidade, promovido pelo Núcleo de Estudos sobre Performance, Patrimônio e Mediações Culturais. Na ocasião, pudemos retomar algumas experiências recentes em torno da peculiar mediação promovida pelo cinema, ao colocar em diálogo os saberes tradicionais e o conhecimento produzido pela universidade. Mais diretamente, este artigo origina-se das inquietações surgidas na mesa-redonda intitulada "Os terreiros, as imagens", no VI Colóquio Cinema, Estética e Política, realizado pelo Grupo de Pesquisa Poéticas da Experiência, em parceria com o VIII Festival de Documentários de Cachoeira, em setembro de 2017, no Recôncavo baiano. Impulsionados por uma experiência em curso na Universidade Federal de Minas Gerais (UFMG) - o Programa de Formação Transversal em Saberes Tradicionais - convidamos lideranças das comunidades de terreiro para que apresentassem seu ponto de vista sobre as inúmeras imagens produzidas sobre o povo de santo. $O$ debate contou com a participação de Makota Valdina (do terreiro Nzo Onimboyá, de Salvador), Mãe Mari (do Ilê Axé Pakolè, de Cachoeira), Makota Kidoiale (do quilombo Manzo Ngunzo Kaiango, em Belo Horizonte), Pai Idelson (do Ilê Axé Ogunjá, de Cachoeira), Pai Ricardo de Moura (da Casa de Caridade Pai Jacob do Oriente, de Belo Horizonte) e do ogã Tata Marcelino (do Zogodô Malé Daho Taby, em Cachoeira).

Desde 2014, temos recebido na UFMG mestras e mestres das culturas afro-brasileiras, indígenas e populares que oferecem cursos abertos a alunos de todos os cursos de graduação. ${ }^{1}$ O Programa de Formação Transversal em Saberes Tradicionais foi inspirado pela iniciativa do antropólogo José Jorge de Carvalho, que promoveu - primeiramente na Universidade de Brasília (UnB) - o encontro entre o conhecimento tradicional e o acadêmico, criando condições para que os múltiplos saberes dos povos afro-brasileiras e ameríndios encontrassem um lugar uma brecha que fosse - em meio a um ambiente intelectual dominado pela mono-episteme ocidental, eurocêntrica e branca. ${ }^{2} \mathrm{O}$ que tem nos guiado é o desejo de conceder hospitalidade a sujeitos, modos de vida e pensamento que prosseguem seu curso histórico - entre resistência e invenção - livres das amarras do conhecimento predominantemente eurocêntrico que sustenta a formação oferecida pelas universidades brasileiras.

Como escreveu Isabelle Stengers ao prefaciar o livro de Tobie Nathan - Não estamos sozinhos no mundo (título retirado de um provérbio iorubá) - a hospitalidade concedida àquele que vem de mundos governados pela presença de deuses e - acrescentamos - orixás, inquices, voduns, caboclos, preto-velhos ou animais-espíritos (como acontece com certos povos ameríndios) requer uma construção ativa e

\footnotetext{
${ }^{1}$ Até agora (2018), tivemos vinte e um cursos e recebemos quarenta e sete mestras e mestres, de diferentes regiões do país. As ementas dos cursos e a identificação das mestras e mestres estão disponíveis no site: <www.saberestradicionais.org>. Acesso em: 27 dez. 2018.

2 Criado por iniciativa do Instituto Nacional de Ciência e Tecnologia de Inclusão no Ensino Superior e na Pesquisa (INCTI), o projeto Encontro de Saberes atualmente abriga uma rede de universidades parceiras: UECE (Ceará), UFMG e UFJF (Minas Gerais), UFPA (Pará) e UFSB (Bahia). Cf. www.inctinclusao.com.br
} 
negociada (STENGERS, 2001, p. 15). A prática cotidiana de acolhimento ao outro, tão marcante nos terreiros, merece todo cuidado e atenção, assim como se faz com a "comida de santo". Entretanto, na direção inversa, quando o cinema chega aos terreiros, sua atitude - não poucas vezes - é a de um visitante cuja curiosidade converte-se facilmente em um olhar intrusivo ou até respeitoso, mas superficial. Em retribuição às comunidades de terreiro que se deixaram filmar tantas vezes, como é que o documentário, em particular, poderia fazer das imagens e dos sons um sítio de hospitalidade, ao abrigar a alteridade dos sujeitos filmados, sem perder de vista os conflitos e os dissensos, e sem também apagar as marcas do lugar social daquele que filma?

Nesse encontro com as mestras e mestres que ocorreu em Cachoeira, Makota Valdina denunciou o quanto fizeram mal ao povo de santo as imagens produzidas sobre os terreiros, pois várias delas desrespeitaram a humanidade dos seus integrantes e frequentadores. Até mesmo no caso das pesquisas antropológicas, as comunidades pouco se reconhecem na identidade que lhes é atribuída pelos pesquisadores, ela enfatizou. Pai Ricardo de Moura, por sua vez, mencionou a "gula daqueles que querem capturar as imagens do outro". Para ele, um dos maiores problemas reside no fato de que as imagens não conseguem apreender nem o saber nem o caminho percorrido para obtê-lo, realizado pelos que experimentam cotidianamente o axé em suas vidas.

Diante de tais dificuldades, como criar uma cena fílmica coabitada pelos sujeitos das comunidades de terreiro e por aqueles que os filmam, permeada pela polissemia e pela abertura de sentido, longe das visões reducionistas acerca da umbanda e do candomblé? Tomemos um exemplo simples, mas potente. Em uma das aulas do curso "Catar folhas: saberes e fazeres do Povo de Axé" (realizada no âmbito do Programa de Formação Transversal em Saberes Tradicionais da UFMG), Pai Ricardo de Moura solicitou aos alunos que trouxessem imagens do povo de santo. Os alunos levaram o desenho de uma pomba gira cigana, a imagem de uma das iaôs fotografada por José de Medeiros, publicada na sensacionalista reportagem para a revista $O$ Cruzeiro em 1951, além de outras representações genéricas do candomblé e da umbanda facilmente encontradas na internet. Pai Ricardo olhou as imagens, uma a uma, e disse - para espanto dos alunos: "mas eu não estou vendo vocês aqui...Porque não trouxeram um retrato seus? Vocês não se vêm do lado de cá, vestidos de branco e com as guias no pescoço"?

Sem ignorar que a participação de brancos (dos extratos mais pobres às camadas ricas) e negros (em situação marcadamente desigual, em virtude do racismo que sobre eles recai) se dá diferenciadamente, tanto nos universos da umbanda quanto do candomblé, podemos afirmar que no exemplo acima ressoa algo daquela identidade relacional adoecida na qual a branquitude fez do Negro o seu Outro, nele projetando, imaginariamente, as fantasias que o negavam, ao lhe atribuir aspectos que ele, Branco, reprimia em seu próprio self (nos termos de Grada Kilomba, inspirada por Frantz Fanon): 
Dentro dessa infeliz dinâmica, o sujeito Negro torna-se não apenas o 'Outro' - o diferente, em relação ao qual o 'self' da pessoa branca é medido - mas também a própria 'alteridade' - a personificação de aspectos reprimidos do 'self' do sujeito branco. Em outras palavras, nós nos tornamos a representação mental daquilo com o que o sujeito branco não quer se parecer (KILOMBA, 2017, p. 27).

Para boa parte dos alunos que participavam do curso, o "lado de lá" - onde se situavam o Zelador e alguns membros da Casa de Caridade Pai Jacob do Oriente - estava correlacionado, de maneira confusa e ambígua, com os universos da população negra e das religiões afro-brasileiras, amalgamados em signos díspares, sob a forma de um Outro do qual eles se viam separados. Quanto aos professores da universidade que acompanhavam o curso, situados do "lado de cá", eles não se sentiram menos inquietos, pois a fronteira entre os dois lados se revelou subitamente, deixando ver as desigualdades materiais e simbólicas que opunham os "objetos" aos sujeitos de saber. Este problema não é de hoje, mas alguns de seus componentes, até então encobertos ou sufocados, ganharam uma forte proeminência nos nossos dias. Tomemos agora um exemplo do cinema.

Há quase quarenta anos, o dossiê "O negro no cinema brasileiro", publicado pela revista Filme Cultura, trazia depoimentos de atores e realizadores negros (Ruth de Souza, Antônio Pitanga, Zózimo Bulbul, Zezé Mota e Odilon Lopez) que relatavam casos de discriminação sofridos, criticavam a ausência de papéis para atores negros e o fato de que os filmes sobre os negros era feitos, em sua maioria, por diretores brancos. À época, no plano dos estudos cinematográficos, e especialmente no campo do documentário, o racismo não aparecia como um elemento relevante para a pesquisa em torno da composição das "imagens do povo" - para lembrar o título do importantíssimo livro de Jean-Claude Bernardet (1985). Por força da conjugação (nada simples) entre o repertório teórico dos estudiosos e o seu próprio lugar social, a importância concedida à opressão de classe encobria a opressão racial (e, mais ainda, a de gênero). De fato, dentre as figurações do povo no documentário brasileiro das décadas de 1960 e 1970, várias delas concerniam ao povo negro, com destaque para os aspectos ligados ao trabalho e à religião.

Não é o caso de atribuirmos uma preocupação do nosso tempo às hipóteses de trabalho que moveram pesquisadores em outras épocas, e sim de destacar um veio do problema que permanecia, até pouco tempo, invisível. Ou melhor, oculto para determinados pontos de vista, o nosso, pesquisadores brancos da universidade. Porém, a insurgência de discursos e obras protagonizados por mulheres e homens negros que tomaram a palavra em diferentes contextos da vida social - sem separar o pensamento crítico da militância ou da criação artística - permitiram abordar o racismo (em suas diversas manifestações) a partir das intersecções entre classe, raça e gênero.

Tendo em vista a questão que nos interessa mais de perto, no caso do cineasta, em seu trato com sujeitos, classes e grupos sociais não apenas distantes do seu universo de experiências e valores, mas 
implicados estruturalmente em relações de desigualdade com o extrato social a que ele pertence, o seu trabalho de mediação vê-se hoje fortemente desestabilizado por três fatores: as reivindicações em torno da auto-representação por parte daqueles que foram sistematicamente silenciados ao longo da história; a denúncia do lugar de fala pretensamente universal assumido pelos sujeitos brancos; a desconstrução crítica do que Grada Kilomba, chamou de "o traumatizante contato com a violenta barbaridade do mundo branco" (KILOMBA, 2017, p. 28).

Pensemos na performance de Michelle Mattiuzzi em Experimentando o vermelho em dilúvio II, de 2016, feita em interlocução com o trabalho de Kilomba em Plantation memories: episodes of everyday racism. ${ }^{3}$ Vestida com uma máscara como a da escrava Anastácia, confeccionada com três peças de metal furadas que lhe tampam a boca, presas por uma fita vermelha afixada com agulhas no rosto e na cabeça, a artista negra caminha pelas ruas do centro do Rio de Janeiro, rumo ao Monumento dedicado a Zumbi, na praça Onze. Com a cabeça do herói de Palmares ao fundo, ela começa a se desfazer da máscara, retirando lentamente as agulhas (primeiro, a da testa), e o sangue principia a escorrer, lentamente, até alcançar o colo e os seios, pingando pelo queixo (como veremos no desenrolar da ação). Quando se retira a agulha que prendia a fita vermelha na face direita, enxergamos (com assombro) as três agulhas que the trespassam os lábios, de baixo para cima, em meio ao sangue e a espessa saliva. Inscrito no rosto, a dor e o sofrimento duram.

Nessa perturbadora cena ritualizada que rememora o trauma das violências sofridas pela população negra desde a escravidão até os dias de hoje, o espectador é desafiado a não desviar a olhar, impedido de lançar mão da denegação que tornaria mais confortável não ver a retirada da máscara e "aceitar" que ela continuasse a tampar a boca, a impedir a fala e a esconder o rosto da artista. Depois de algumas passagens pontuadas por uma canção dos negros aprisionados nas penitenciárias americanas No more, my Lawd - a sequência final coloca no mesmo plano a cabeça de Zumbi e o rosto de Michelle Mattiuzzi, para terminar com o punho dela, cerrado, levantado, ao lado da cabeça do herói negro ${ }^{4}$. O gesto, de uma insurreição no presente, não só rememora as lutas do passado e convoca paras as novas, do presente, com desconstrói a homenagem oficial ao herói realizada pelos poderes do Estado ao criar o monumento (concebido por Darcy Ribeiro, à época vice-prefeito do Rio de Janeiro, na gestão de Leonel Brizola).

Interpelados pelas intervenções recentes que questionam e deslocam os lugares instituídos que autorizam quem pode falar de quem e do quê - como é o caso da reivindicação de Djamila Ribeiro em torno do conceito de lugar de fala como instância política e epistemológica - de

\footnotetext{
${ }^{3}$ Foi Amaranta César quem nos apresentou o registro dessa performance, por ela comentada no III Encontro Internacional da Imagem Contemporânea, realizado em Fortaleza, de 26 de fevereiro a 1 de março de 2018. Cf. a programação está disponível em: <http://www.eiic.ufc.br/2018/>. Acesso em: 27 dez. 2018.

${ }^{4}$ Não conseguimos identificar a autoria da versão utilizada no vídeo da performance, mas ficou conhecido o registro desta canção feito por Alan Lomax em 1947, na prisão de Parchman, Mississipi.
} 
que maneira nós (realizadores, espectadores, críticos e pesquisadores) poderíamos rever criticamente a intrusão imagética que o cinema promoveu e continua a promover quando aborda as manifestações religiosas de matriz africana em nosso país? (RIBEIRO, 2017, p. 83-90). Sublinhemos que, tal como o fez Amaranta César ao comentar a performance de Michelle Mattiuzzi, no caso dos estudos e da crítica cinematográfica, movemo-nos no campo de uma institucionalidade branca, e isso marca indelevelmente nosso discurso. Mais, ainda: como realizar essa crítica a partir da contribuição das vozes e dos pontos de vista dos sujeitos das comunidades filmadas, colocando em questão os lugares e os sujeitos até então autorizados a conduzir o gesto crítico, legitimados em sua dimensão tanto social quanto epistêmica?

Aproximamos abruptamente universos e conhecimentos distintos, separados por uma forte dissimetria, produzida pelo prestígio conferido pelas instituições da cultura ao cineasta, que assina sua obra, e o anonimato dos sujeitos filmados, cujos nomes próprios são frequentemente elididos, e que só podem contar com seus rostos e corpos para singulariza-los. Se assim fazemos é porque só muito recentemente surgiu a possibilidade de criar uma interlocução entre cineastas, críticos e pesquisadores em cinema - cuja sensibilidade é formada pela familiaridade com os recursos expressivos da imagem técnica e com a teoria fílmica - e as mestras e mestres dos saberes tradicionais, que ancoram seu saber tanto na experiência legada pela ancestralidade quanto no enfrentamento com os desafios do presente. (Numa bela e precisa formulação, Pai Ricardo de Moura costuma afirmar: "Eu sou contemporâneo da minha ancestralidade").

Se os povos de matriz africana já foram figurados (no documentário e na ficção), de diferentes maneiras, dando a ver - em meio a preconceitos e visões distorcidas - seus modos de vida e práticas rituais, podemos perguntar pelas novas modalidades de figuração possíveis atualmente, quando as comunidades tradicionais afrodescendentes tornam-se protagonistas dos discursos de emancipação e assumem, sob diversas formas, sua auto-representação. Como delinear as novas condições e perspectivas de que o cinema (documentário e de ficção) dispõe para abordar, em nova chave, outros aspectos da vida subjetiva e coletiva nos terreiros? Ao criticar a ênfase excessiva concedida - pelos que vem de fora, acadêmicos e cineastas - ao que eles julgam ser "o sagrado dos terreiros" ou sua importância sócio-cultural, Makota Valdina sugere que fazer um filme sobre o racismo que os negros sofrem no ônibus já seria uma boa maneira de ajudar os terreiros. Ou ainda: porque não se fala da cura que os terreiros proporcionam aos que nele vivem e aos que os procuram? Para levar mais adiante essas indagações, faremos um breve recuo no tempo.

O programa do pioneiro seminário "Cinema e descolonização", promovido pela Sociedade de Estudos da Cultura Negra em 1981, em Salvador, reuniu cineastas, antropólogos, artistas, críticos e pesquisadores do cinema, mas, ao que parece - pelos registros que ficaram - poucos mestres dos terreiros (dentre eles, Deoscóredes Maximiliano dos Santos, o 
Mestre Didi, Assobá do Axé Opô Afonjá, e o Babalorixá Nilson Feitosa). ${ }^{5}$ Nesse evento, a antropóloga e cineasta Juana Elbein dos Santos criticou os códigos culturais dos profissionais de cinema e reivindicou uma reformulação simbólica que permitisse às comunidades expressarem sua visão de mundo, provisória e estrategicamente mediada pelo trabalho dos cineastas. Adquiridos os instrumentos necessários à sua própria expressão, as comunidades poderiam escolher se fariam ou não cinema (XAVIER, 1982, p. 24). Ismail Xavier resumiu do seguinte modo a intervenção de Juana Elbein dos Santos nesse debate:

Há duas ordens de questões. A primeira é o arsenal de códigos culturais (tomados como verdades técnicas) que o profissional do cinema traz consigo - é, no momento, impossível contar apenas com os membros das comunidades negras para realização e o trabalho envolve profissionais com distintas experiências. A segunda é a pesquisa de linguagem necessária para operar o que Juana denominou "reformulação simbólica" ou "re-codificação simbólica", processo de encontrar os procedimentos especificamente cinematográficos capazes de traduzir o sistema simbólico da comunidade, capazes de fazer do cinema um lugar onde a comunidade vê expressos os seus valores e a sua "visão de mundo" e vê retrabalhada a sua tradição e a identidade em novos termos, de modo a contribuir para que ela se processe dinamicamente no presente e não apenas celebre sua memória congelada, estática e separada da experiência atual (XAVIER, 1982, p. 24).

Nesse mesmo seminário, ao comentar o filme de Juana Elbein dos Santos, Ya-mi Agbá - Mito e metamorfoses das mães nagô (1979), exibido no evento, Jean-Claude Bernardet afirmou que, para que a "voz do dono do discurso" não abafasse a "voz do outro" filmado, seria preciso uma evolução (o termo é dele) que envolveria "não apenas o documentário e o cinema, mas a estrutura global da sociedade e, dentro dela, a função política do saber" (XAVIER, 1982, p. 29). Um pouco antes, no início da década de 1980, numa conversa entre realizadores, pesquisadores e críticos, publicada na revista Filme Cultura, ao comentar sua experiência com os índios Canela, no Maranhão e as possibilidades inauguradas pelo vídeo, Andrea Tonacci afirmara que começava a "nascer para a comunidade a própria imagem dela" (TONACCI, 1980, p. 9). ${ }^{6}$ Bernardet, que participava da conversa, acrescenta que conhecera o trabalho de Juana Elbein dos Santos, que filmava em Itaparica, sem os recursos do vídeo, mas a partir da discussão com as pessoas da comunidade. Comparado ao documentário feito na década 1960, frisa Bernardet, os filmes de Tonacci e Juana Elbein inauguravam um novo modo de se fazer cinema: "Eu acho que estão crescendo as sensações de existe um outro poder, uma outra sociedade, outras maneiras de se aproximar do Brasil" (TONACCI, 1980, p. 9).

\footnotetext{
${ }^{5}$ A revista Filme Cultura, encarregada de cobrir o evento, trouxe um relato feito por Ismail Xavier, inserido no dossiê "O negro no cinema brasileiro (n. 40, ago/out. 1982).

${ }^{6}$ Prá começo de conversa. Filme Cultura n. 34, 1980. Participaram dessa conversa Andrea Tonacci, David Neves, Luiz Rozemberg, Teresa Trautman, Ismail Xavier, Jean-Claude Bernardet, José Carlos Avellar, Sérgio Santeiro e Zulmira Ribeiro Tavares.
} 
Se retornamos às ideias instigantes de Bernardet é porque, ao longo dos anos, algumas das suas proposições ganharam valor paradigmático pela atenção concedida aos documentários "inquietos tanto com os problemas sociais como com os de linguagem":

Sob a influência da evolução política posterior ao golpe de 1964, dos movimentos sociais que foram abafados ou conseguiram se expressar, do questionamento relativo ao papel dos intelectuais, das diversas revisões por que passaram as esquerdas, do aparecimento das "minorias" que colocaram a questão do Outro, da evolução do Cinema Novo e da perda da sua hegemonia estética e política, das preocupações quanto à linguagem cinematográfica, ao realismo e à metalinguagem, esse cinema documentário viveu uma crise intensa, profundamente criadora e vital (BERNARDET, 2003, p. 12). ${ }^{7}$

$\mathrm{Na}$ análise que Bernardet dedicou aos filmes que tematizaram o candomblé sobressai a maneira com que ele equacionou a relação entre os procedimentos expressivos do filme e a alteridade própria do sagrado. A incógnita dessa equação pode ser assim resumida: se determinadas manifestações do sagrado interditam o olhar daquele que não participa presencialmente do ritual - e que só pode compreendê-lo por meio da defasagem da imagem em relação ao fenômeno filmado (para retomar os termos de André Brasil) -, o que pode então um filme diante dessa situação? (BRASIL; BELISÁRIO, 2016, p. 605). ${ }^{8}$ Como sua escritura consegue lidar com esse impedimento constitutivo?

A solução encontrada por Juana Elbein em Ya-mi Agbá - Mito e metamorfoses das mães nagô - na leitura de Bernardet - foi criar uma tensão entre interioridade e exterioridade. De início, o mito das mães ancestrais é interiorizado pela linguagem criada pela cineasta, em dois movimentos: o filme se abre com o poema nagô, lido por Annelise Cabral, dedicado às "grandes mulheres ancestrais", associado às imagens de diferentes aves, sob os efeitos da desaceleração, da parada e do desfocalização. Em seguida, a locução (conduzida por Ferreira Gullar), de teor antropológico e explicativo, vincula o universo de trabalho das mulheres negras ao poder das Iya-agbá. Elas, "que enchem as ruas e os carnavais", e que "estão nas roças, nas fábricas, nas feiras", são Iyá. "A brasileira negra mantém intacto o mítico poder das Iya-agbá; o poder herdado de suas mães ancestrais", afirma o narrador. Em uma das mais belas sequências do filme, vemos uma breve série de mulheres negras em seu trabalho cotidiano nas feiras e mercados, até surgir uma jovem mulher grávida, com seu ventre/cabaça ancestral. Segundo Bernardet, "o filme nos mostra imagens a um tempo ligadas à cosmogonia e distanciadas dos rituais. Essas imagens só existem no e para o filme (BERNARDET, 2003, p. 29). Se o filme não pode, por si só, apanhar o valor simbólico do mito enquanto força atuante no mundo (manifesta nas

\footnotetext{
${ }^{7}$ A primeira edição do livro é de 1985 , pela editora Brasiliense.

${ }^{8} \mathrm{Em}$ seus artigos dedicados ao cinema indígena, André Brasil tem chamado atenção para o fato de que, por mais que esteja materialmente implicada na situação de filmagem, a câmera guarda sempre uma distância, um hiato espaço-temporal diante do fenômeno filmado. É isso que o autor chama de defasagem constitutiva do cinema.
} 
palavras, cantos e danças), ele pode, entretanto, interiorizar o sagrado nas invenções proporcionadas pelas operações da montagem.

Já a exterioridade, que orienta a segunda parte do filme, permite que se fale (de fora) da significação simbólica das danças dos orixás femininos, com sua gestualidade, paramentos e ritmos próprios. Se no procedimento de interiorização do mito o valor referencial (individuado e singular) das imagens convive - sem se destacar - com a significação (genérica e convencional) que lhe é atribuída inicialmente pelo poema nagô e, em seguida pela locução que explica os simbolismos em jogo no mito cosmogônico, no procedimento da exteriorização, de caráter didático e demonstrativo, a singularidade das imagens é propositadamente atenuada ou diminuída. Fora da situação ritual, pode-se executar a dança específica de um orixá e explicar o seu significado, pois as imagens tem caráter de exemplo. (Tal como Juana Elbein fizera no seu admirável filme anterior, Orixá Ninu Ilê, de 1978).

Comparados à inventiva estratégia expressiva empregada por Juana Elbein em Iya-mi Agbá, os procedimentos utilizados por Geraldo Sarno em Iaô - A iniciação num terreiro gege nagô parecem condenados a uma má exterioridade. (Lembremos que Sarno inspirou-se em Os nagôs e a morte, livro de Juana Elbein). Mesmo o cineasta tendo mostrado, em cena, que se ele filma tão de dentro e de tão de perto é porque se submeteu aos procedimentos da casa de Mãe Filhinha, que Ihe concedeu essa permissão, ainda assim - afirma Bernardet (2003) - isso não incide na construção dramática do filme. Vista com os olhos e, sobretudo, com as preocupações de hoje, a contraposição estabelecida por Bernardet pode ser compreendida sob outro ângulo. O texto dedicado ao filme de Juana Elbein, publicado originalmente na revista Filme Cultura em 1982 foi remanejado e correlacionado com três outros filmes (Gilda, Destruição cerebral, e Iaô) sob o emblema de uma indagação mais ampla: constituiria o outro filmado um segredo inacessível ao filme?

No caso do contraste entre Ya-mi Agbá - Mito e metamorfoses das mães nagô e Iaô - A iniciação num terreiro gege nagô, sublinhemos que os dois não tratam do mesmo assunto, possuem abordagens distintas e estão às voltas com preocupações diferentes. Uma coisa é recontar o mito das mães ancestrais com os meios da imaginação e da montagem, feito por alguém que conhece de dentro o universo filmado (e não apenas por causa do saber antropológico dominado pela autora). Bem distinta é a situação daquele estranho que chega pela primeira vez à comunidade e se põe a filmar os seus espaços (o urbano, o mato e o rio) e os rituais que ali ocorrem. O que nos chama atenção neste filme de Sarno não são apenas seus enganos e incompreensões, mas também o seu fascínio diante daquilo que lhe aparece e que, a certa altura, ele se põe a filmar sem saber, intransitivamente (pois já não se trata mais de enunciar algo em torno de um evento ou de um espaço, transformando-os em objeto de conhecimento, tal como ocorrera na primeira parte do filme).

O critério principal que sustenta a contraposição estabelecida por Bernardet entre os filmes de Juana Elbein e Geraldo Sarno baseia-se em dois postulados: interdição de filmar os rituais secretos, e a oposição 
entre a imediatidade presencial da manifestação do sagrado à mediação da imagem, governada pela temporalização e pela retração que ela promove (como todo signo) diante do seu objeto. Quanto ao primeiro postulado, o que temos visto é que cada casa, em cada situação, é quem define o que pode e o quer expor, em quais condições e para quem. $O$ princípio ético que deve orientar o documentarista, parece-nos, é o de respeitar inteiramente o desejo de quem é filmado e de negociar com ele sua entrada em cena. (Sabemos que Iaô, o filme que visitou pela segunda vez o terreiro de Mãe Filhinha, abriu na comunidades filmada uma ferida que até hoje ainda não se fechou, pois ao se filmar as iaôs no interior do roncó - ainda que sob o consentimento da Ialorixá - um interdito foi rompido e algo da tessitura das relações com o sagrado se viu exposto pelos meios do cinema).

Quanto ao segundo postulado, duas considerações podem ser feitas. A mediação da imagem não deveria ser julgada apenas negativamente, pelo déficit, pelas perdas ou pela incapacidade de dar a ver e a compreender os atributos do fenômeno filmado. Nos termos de Marie-José Mondzain, a mediação imagética implica a construção de uma vinculação entre o visível, o invisível e o olhar e as palavras que os põem em relação (MONDZAIN, 2009, p. 26-27). Toda mediação solicita uma pragmática acrescentamos - e não possui traços intrínsecos, invariáveis e universais. E quanto ao sagrado, seria mais interessante defini-lo como uma rede de sentido e de afecções que instaura relações intricadas entre o socius e o cosmos, acionadas sob certas condições e por meio de procedimentos, artefatos, eventos, rituais, cantos e palavras segundo uma adequação conhecida por aqueles que detém uma experiência e um saber reconhecidos pela comunidade.

$\mathrm{Na}$ abertura do curso "Catar folhas: Saberes e Fazeres do Povo de Axé" na UFMG, em 2016, após os toques dos atabaques, os cantos e as falas das mestras e mestres convidados, exibimos o filme Espaço Sagrado (1975), de Geraldo Sarno, o primeiro filme que Sarno dedicou ao terreiro de Dona Filhinha, o Ilê Axé Itaylê, em Cachoeira. Durante a projeção, na segunda metade do filme, houve um momento em que a dimensão encantatória e invocatória do canto a Iemanjá Ogumté e dos gestos das iaôs recém-iniciadas, tomadas pouco a pouco por um transe suave, parecia que a canoa levada pelas águas do rio Paraguaçu tinha como paisagem de fundo as árvores que nos protegiam da iluminação dos postes e criavam uma sala de cinema a céu aberto. Como é que esses cantos, rostos e corpos nos alcançaram naquela noite, fazendo dos que ali estavam os seus novos espectadores? Se essas imagens e cantos conseguiram guardar o tempo em si mesmos não seria porque "o cinema não reproduz corpos, eles os produz com grãos, que são grãos de tempo", como dizia Gilles Deleuze (2016, p. 307)?

Ao abandonar a explicação antropológica da sua primeira metade, o filme se deixa imantar pelos valores intensivos da imagem manifestados na gestualidade peculiar do ritual, nos afetos encarnados no rosto dos participantes, nos cantos (sobrepostos à imagem ou registrados em som direto) e, em especial, na atenção conferida à Mãe Filhinha, que conduz a 
cerimônia dedicada a Iemanjá. Nas imediações da Pedra da Baleia, uma das moradas daquela "cujos filhos são peixes", a cena é tomada pela ondulação cadenciada dos gestos da Ialorixá. Na margem do Paraguaçu, ao som dos atabaques e do gan, Mãe Filhinha executa movimentos com os ombros e o pescoço, como se o barco-cesta no alto de sua cabeça preparasse sua entrada na água. No breve plano que se segue, quando ela cumprimenta um homem de guia azul no pescoço, surge uma pausa, o som dos instrumentos cessa (não por obra da montagem, pois vemos que um dos ogãs interrompeu o seu toque). Logo um novo canto - desta vez sobreposto à imagem - faz a passagem para o plano seguinte, que traz Mãe Filhinha e as Iaôs recém-feitas na canoa. Até então filmado em som direto, o ritual é submetido às operações da montagem, que sobrepõe dois cantos à imagem da canoa no rio. Com isso, a duração partilhada pela máquina e os sujeitos filmados, experimentada sensivelmente pelos espectadores, é interrompida.

Nos planos-sequência seguintes, a câmera se aproxima mais da embarcação, à procura de novos enquadramentos, sem pressa. Assim que as oferendas são lançadas nas águas, o transe chega suavemente; primeiro com Mãe Filhinha, e depois com as Iaôs. Vemos mais de perto o evento filmado, graças aos recursos do dispositivo técnico, mas também ficamos mais longe (longe de apreender o que se passa na imagem, à qual foi associado um canto que não fazia parte do evento filmado). À medida que a canoa retorna à margem, o segundo canto se destaca, por obra da montagem, outra vez. Tal como o filme, indeciso na combinação do registro direto e da montagem sonora, os espectadores ficam encantados diante do que vêm e escutam, mas impossibilitados de alinhavar o sentido entre as sequências. Os cinco planos que se seguem acentuam ainda mais a descontextualização: a proa da canoa aproxima-se da moça estendida na margem, que será auxiliada pela Ialorixá; Mãe Filhinha dança ao som dos atabaques (em plano mais fechado, noturno), e em seguida ela se deita no solo (numa forma de cumprimento ritual). No último plano, faz-se uma roda de mulheres que dançam em torno dela.

Atuando tanto na vida cotidiana quanto nos rituais (secretos ou realizados nas festas públicas), o segredo do sagrado não deixa de reinar quando a imagem se expõe (mesmo se ela não se deixa levar pelos possíveis equívocos promovidos pela montagem). A grande questão, porém, é que nós, espectadores desprovidos da experiência do axé, "não vemos o que age na imagem", como afirmou Pai Ricardo de Moura em uma de suas aulas na UFMG. Isso coloca tanto o cineasta (e sua equipe) quanto os espectadores diante de uma dupla responsabilidade, ao mesmo tempo ética e estética. Para quem filma, todo um trabalho em torno da mediação a ser construída: como abordar os variados e singulares aspectos da vida nos terreiros, preservando a alteridade que lhes é constitutiva? E para os que vêm o filme, que lugar nos é destinado a assumir, juntos, quando nos vemos diante da imagem desses mundos outros? Como podemos, por meio do filme, instituir uma coabitação entre mundos distintos, mas de tal maneira que o nosso lugar não seja mais o centro de onde emana o ponto de vista preponderante (branco e 
eurocêntrico) de onde vemos (e julgamos) o mundo do outro? Como é que os filmes poderiam fazer surgir, entre os espectadores, um mundo comum multi-perspectivado, descentrado, orientado pela relação com o seu fora, e firmado tanto na coexistência entre os diferentes quanto na exposição ao outro?

O cinema bem que poderia se colocar à escuta de outras vozes, como neste ponto do caboclo Ubirajara: "Deus quando fez o mundo/Não fez de brincadeira/Fez mundo grande/Fez terra alheia" (Trata-se do canto entoado por Mametu Muiandê/Mãe Efigênia, do Manzo Ngunzo Kaiango, uma das mestras que atuou nos cursos dos saberes tradicionais oferecidos na UFMG, no vídeo-retrato que dela fizemos) ${ }^{9}$. No diálogo com o universo ameríndio mantido pela umbanda, não há na cosmologia dos povos negros que se recriaram pela diáspora esse princípio que, contrariando a propriedade e os proprietários, vê o começo do mundo na sua abertura aos outros, a todos os outros (humanos e não-humanos, espíritos, animais, plantas e outros elementos da natureza)? Um mundo aberto à alteração diante da presença (fundadora) desses outros, fora de si, na terra alheia, alhures, animado pela relação com outrem (NANCY, 2004, p. $9-43) .{ }^{10}$

Por fim, gostaríamos de lançar uma hipótese de trabalho (a ser desenvolvida posteriormente) que investigasse as condições históricas e os procedimentos expressivos inventados pelos filmes (sob circunstâncias específicas) que permitiram o aparecimento dos relatos carregados da dimensão subjetiva da experiência religiosa vivida nos terreiros de candomblé e umbanda. É provável que boa parte dos filmes realizados nas décadas de 1980 e 1990 estivessem num front abertamente político, interessados em buscar razões históricas e sociais para compreender a situação da população negra do país e os gestos de resistência dos movimentos sociais, intelectuais e artistas e também, das pessoas comuns, conscientes da perpetuação da escravidão sob novas formas, como testemunham Abolição (1988), de Zózimo Bulbul e o Fio da memória (1991), de Eduardo Coutinho.

Entre nós, demorou muito para que os sujeitos filmados pudessem falar da experiência religiosa nos seus próprios termos, liberados da moldura do discurso explicativo de tipo sociológico ou antropológico (pensemos em Santo Forte, de Eduardo Coutinho, que é de 1999). Seria preciso também mapear as muitas aparições incidentais do tema em diferentes filmes, como aquela, emblemática, de Aniceto do Império, no filme de Zózimo Bulbul, Dia de alforria...? (1981): no cais do porto, tendo por trás uma embarcação de nome Palmares, ao mencionar que nascera em 1912 numa segunda-feira de Omolu e que vive "sob a proteção das almas santas e benditas", o sambista, estivador e sindicalista se agacha e

\footnotetext{
${ }^{9}$ Disponível em: <www.saberestradicionais.org>. Acesso em: 27 dez. 2018.

${ }^{10}$ Retomamos livremente, por nossa conta e risco, algumas das formulações do filósofo Jean-Luc Nancy no seu esforço de desativar o pensamento vigente em torno da noção de comunidade (guiada pela metafísica da comunhão, fechada em uma imanência absoluta, regulada pela soberania do sujeito) e virá-la para o seu fora, exposta à (co) existência das/com as singularidades.
} 
toca com os dedos uma pequena mureta, reverenciando suas entidades protetoras.

Nesse contexto, o filme Orí (1989), de Raquel Gerber se situa numa encruzilhada de possibilidades, ao se servir de diferentes estratégias expressivas. Contando com o roteiro e a narração de Beatriz do Nascimento, mulher negra, historiadora e militante, o filme mescla diferentes registros: ensaístico, autobiográfico, lírico e, em certas passagens, discretamente etnográfico. Ao caracterizar a diáspora africana como perda da imagem de si, no exílio, e ao identificar os elos de uma história fragmentada entre os continentes africano e americano, Beatriz do Nascimento recusa o "eterno estudo do escravo" e caracteriza os quilombos como uma organização social de homens livres, resultantes do ato (a fuga) do "homem que reconhece que não é propriedade de outro". ${ }^{11}$ O filme traz o registro de uma intervenção de Beatriz na Quinzena do Negro, evento realizado na Universidade de São Paulo (USP), em 1977, quando, dentre outras questões, reivindicava-se a ampliação do acesso da população negra às universidades brasileiras. Em sua fala, a historiadora afirma que, para além da questão econômica, o grande drama está no "reconhecimento da pessoa do homem negro, que nunca foi reconhecido no Brasil".

Conduzido pela narração e pelo olhar de Beatriz, Orí compõe um mosaico de imagens, atos, tomadas de palavra, manifestações, atitudes, gestos corporais, cantos, músicas e danças nas quais o povo negro recria e afirma sua identidade de múltiplas maneiras. Ele "faz a sua cabeça" (Orí) nos mais diferentes contextos: no terreiro Ilê Xeroquê, nos desfiles das escolas de samba São Miguel Paulista e Vai-Vai, no show da banda Black Rio, no baile soul frequentado pela juventude negra, nos eventos e manifestações do movimento negro nas décadas de 1970 e 1980 . Mulheres negras e homens negros, conhecidos e anônimos, pensadores, artistas, intelectuais, ativistas, mestras e mestres, persistiram e persistem em suas diversas práticas, saberes, pesquisas e criações, espalhados pelo nosso país. Se eles permanecem invisíveis para nós é porque ainda não nos demos conta do quanto nosso olhar e nossa compreensão são limitados pelo lugar que ocupamos. Não vemos de onde vemos o outro. Daí a tarefa política e epistemológica de criar condições para que, na companhia deles, em relações simétricas (que não impeçam o dissenso nem recalquem a divergência), possamos transformar as instituições a que pertencemos e combater - em várias frentes - o racismo estrutural que as conforma de dentro. Podemos começar por ver juntos com os outros as imagens que nosso mundo fez deles.

\section{Referências}

BERNADET, J.-C. Cineastas e imagens do povo. São Paulo: Brasiliense, 1985.

11 Juana Elbein dos Santos, na plateia, entra no debate que se instala com a intervenção de Beatriz do Nascimento e reforça que, na concepção de Beatriz do Nascimento, trata-se da definição do quilombo como "continuum cultural de agregação" em um país marcadamente hetero-cultural. 
BERNARDET, J.-C. Mitos e metamorfoses das mães nagô. Filme cultura, Rio de Janeiro, n. 40, p. 28-29, 1982.

BRASIL, A.; BELISÁRIO, B. Desmanchar o cinema: variações do fora-decampo em filmes indígenas. Revista Sociologia e Antropologia, Rio de Janeiro, v. 6, p. 601-634,2016.

DELEUZE, G. O cérebro é a tela. In: DELEUZE, G. Dois regimes de loucos: textos e entrevistas (1975-1995). São Paulo: Editora 34, 2016. p. 299310.

KILOMBA, G. A máscara. Piseagrama - Espaço Público Periódico, Belo Horizonte, n. 11, p. 26-31, 2017.

MONDZAIN, M.-J. A imagem pode matar? Lisboa: Vega, 2009.

NANCY, J-L. La communauté désœuvré. Paris: Christian Bourgois, 2004.

RIBEIRO, D. O que é lugar de fala? Rio de Janeiro: Letramento, 2017.

STENGERS, I. Le laboratoire de l'ethnopsychiatrie. In: NATHAN, T. Nous ne sommes pas seuls au monde: les enjeux de l'ethnopsychiatrie. Paris: Le Seuil, 2001. p. 7-46.

TONACCI, A. Prá começo de conversa. Filme Cultura, Rio de Janeiro, n. 34, p. 4-11, 1980,

XAVIER, I. Cinema e descolonização. Filme Cultura, Rio de Janeiro, n. 40, p. 23-27, 1982. 